\title{
INTERNATIONAL COMMISSION ON ZOOLOGICAL NOMENCLATURE
}

SIR,-Required six-months' notice is given on the possible use of plenary powers by the International Commission on Zoological Nomenclature in connection with the following names, listed by Case Number (see, Bull. zool. Nomencl., 24, pt. 1, 6th March, 1967):

1390. Validation of Bugula and Scruparia from Oken, 1815 (Polyzoa).

1689. Grant of availability for certain "section" names of de Saussure (Hymenoptera).

1692. Suppression of Strix capensis Daudin, 1800 (Aves).

1772. Validation of Ophiura Lamarck, 1801; suppression of ten specific names (Ophiuroidea).

1776. Neotype for Gorgonia flabelliforme Eichwald, 1840 (Graptolithina).

1777. Suppression of Voluta citrina, V. strigosa, and V. leucostoma Gmelin, 1791 (Gastropoda).

1779. Validation of Dicerorhinus Gloger, 1841 (Mammalia).

1783. Validation of Tetrameres Creplin, 1846 (Nematoda).

1784. Validation of Sterna tschegrava Lepechin and Motacilla pleschenka Lepechin, " 1770 " (Aves).

1785. Validation of emendation to Polyxenus of Pollyxenus Latreille, [1802-1803] (Diplopoda).

Comments should be sent in duplicate, citing Case Number, to the Secretary, International Commission on Zoological Nomenclature, $\mathrm{c} / \mathrm{o}$ British Museum (Natural History), Cromwell Road, London, S.W. 7, England. Those received early enough will be published in the Bulletin of Zoological Nomenclature.

W. E. China, Assistant Secretary.

InTERnational Commission on ZoOlogical Nomenclature,

c/o British Museum (NAT. Hist.),

CROMWELL. ROAD,

LONDON, S.W. 7.

February, 1967.

\section{AN IMPROVED TRANSFER TECHNIQUE FOR THE PREPARATION AND PRESER VATION OF PYRITIZED GRAPTOLITES}

SIR,-Polyester resins have long been used to mount fossils of many groups, and the special application of this method to pyritized graptolites preserved in black shale has proved very successful. Pyritized graptolites, although infinitely more valuable than flattened specimens, present several difficulties. Study is facilitated if the specimen can be removed, even partially, from the matrix, but long term preservation is difficult since on exposure to the atmosphere the pyrite decomposes, a process which often begins within a few years of collection.

The normal method of removing the rock matrix is to adfix the specimen with Canada Balsam face downwards to a glass slide, and, whilst protecting the slide with wax, the rock is removed with hydrofluoric acid. The specimen can then be studied in two views (either obverse and reverse, or dorsal and ventral). Some degree of protection can be afforded the specimen by putting on a further coat of Canada Balsam. Similarly, if the specimen is to be left in the rock matrix it can be covered with a thin layer of either Canada Balsam, or Euparal gum (with or without a glass slide), but both these protecting media have the disadvantage of deterioration with age (discoloration, drying and cracking) and need fairly regular attention.

The embedding technique outlined below, in addition to making the specimen visible in all aspects, removes the rock matrix, obviates the need for glass slides, and protects the specimen completely both from moist air and normal wear and tear.

The first step is to trim the rock to within half an inch of the graptolite on all sides, preferably making the walls of the resultant block approximately 


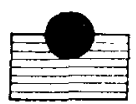

a

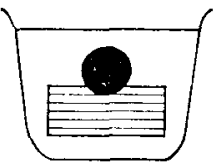

c

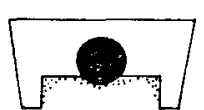

e

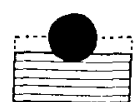

b

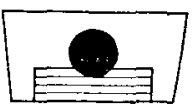

d

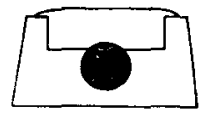

f

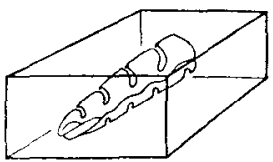

9

Fig. 1

vertical (Fig. 1(a)). With a needle and sharp blade the matrix is then removed as far as possible from the sides of the graptolite (Fig. 1(b)). If this stage can be achieved successfully the graptolite will be thoroughly supported during the subsequent chemical treatment.

The prepared block, specimen uppermost, is submerged in resin held in a polythene container of convenient size (Fig. $1(c)$ ). After about seven days, the resin will have hardened sufficiently for the whole to be removed from the container, and the back ground down to within $\frac{1}{4}$ inch of the graptolite (Fig. $1(d))$. The block is then developed in 60 per cent HF until the rock matrix has either been dissolved or remains as a sludge around the graptolite (Fig. 1(e)). Very careful washing will remove most of the sludge, whilst any adherent rock can be picked away with a needle or dental scraper. It is essential, if the graptolite is to be viewed in all aspects, that this adherent matter is removed and the resin surface made as clean as possible. The specimen is dried by gently warming and a second layer of resin is added to the cavity (Fig. 1( $f)$ ). It is important that the proportions of resin, activator, and catalyst of the two layers are identical, since serious discrepancies may result in differences in colour. Finally, when the second layer has set, the whole block is cut to size and polished.

Crystic 195 and Ceemar are two resins which have been found suitable, neither having any definite advantage over the other. The total life of these resins is not known, but they certainly last at least ten years without noticeable discoloration or cracking. The blocks can easily be repolished if the surfaces become scratched through constant use. It appears that the contained pyrite is protected from deterioration; the general oxidizing nature of the resin does not seem to initiate chemical reaction in the absence of air and moisture.

Although this technique is rather long and delicate (an "assembly line" is probably the most efficient method of dealing with large numbers of specimens), the advantages of both easy storage and viewing, and presumably of nearperfect protection, make it a considerable improvement upon earlier methods.

British Museum (Nat. Hist.),

JANA HUTT.

R. B. RICKARDS.

LONDON, S.W.7. 